\title{
Village Financial Management: Based on Local Tradition
}

\author{
Khairul Shaleh $^{\mathrm{a}}$, Hesty Juni Tambuati Subing ${ }^{\mathrm{b}}$, Andi Ina Yustina ${ }^{\mathrm{c}}$ \\ ${ }^{a}$ Widyatama University, Indonesia \\ ${ }^{b}$ Widyatama University, Indonesia \\ ${ }^{c}$ President University, Indonesia \\ khairul.shaleh@widyatama.ac.id
}

\begin{abstract}
This study aims to formulate village financial management based on local traditions of village communities. The research method uses a qualitative descriptive approach, which is a method that seeks to present a picture of the objective reality that occurs in a condition or environment in a particular place. Environmental context (Site) in this study is Sindang Pakuon Village, Cimanggung District, Sumedang Regency and Ciburial Village, Cimenyan District, Bandung Regency, West Java Province. Presence of village funds is acknowledged to have changed the face of the village which previously seemed neglected, now looks better. Village infrastructure such as village roads is more convenient for motorists and pedestrians. Road to distribution of agricultural products has been built so that the travel time to move agricultural products from the fields to the market location is faster. Although village funds have brought changes to public facilities in the countryside, they have a fading effect on aspects of village tradition. Emergence of this fading is because the nomenclature that regulates the use of village funds does not yet accommodate the local aspects of rural areas.
\end{abstract}

Article Info

- Received : October 12, 2019

- Revised : November 8, 2019

- Published : January 16, 2020

- No. Pages : 23-35

- DOI : 10.33019/ijbe.v4i1.245

- JEL : I22, O18

- Keywords : village financial management, local dimensions of communities, budget nomenclature, integration

\section{Introduction}

Conceptual framework, standard, technical accounting is not merely an instrument to produce financial statements that contain nominal "numbers" (Bay, 2018) as a form of accountability. Toms \& Shepherd (2017) revealed the conception of accounting is a social system that provides a space of interaction between stockholders and stakeholders. Accounting is not only technical but also an instrument of social action that can accommodate the interests of the community (Stakeholders). In the context of government accountability, financial statements produced from the accounting process are social instruments where the government as the producer of financial statements and the public as users are in the same position (egalitarianism). The community has the right to the accessibility of meaning contained in the contents of financial statements even though it is not in the capacity of technical understanding. Brown (2017) argues that realizing the same accessibility to financial statements requires a communication channel that puts the owner and user in line. 
Village financial management likewise places the community in commensurate degrees. The village government as village financial management and society as the orientation of public services in rural areas are at an equal level. Such thinking can shift old habits in which village financial management is discussed in the technical sphere which has so far dominated by technical implementers but goes a step further in understanding it from other aspects namely the traditions and social reality of village communities. So that village financial management must be interpreted and interpreted following the social reality of rural communities. It takes the form of internalizing local values and social realities in the village financial management. The effort is to minimize the cons between development and local values in rural communities.

Village financial nomenclature, which is the basis for the village government to manage village finance, is considered through the socio-cultural point of view of the village community. the description follows the social environment context of the village where the regulation is applied. The effort is a financial policy oriented towards harmony in the rural community environment through village financial management. Differences in nomenclature between village governments can occur because the characteristics of villages from Sabang to Merauke have different geographical and socio-cultural conditions. This situation results in each rural environment having a variety of needs. In this reality, uniformity in the context of nomenclature needs to be set aside to recognize diversity as an objective reality that exists in every rural area in the archipelago. To accommodate differences in each rural environment, it is necessary to formulate a pattern of village financial management based on the socio-cultural reality of the local village community that is the focus of this study.

The construction of village financial management patterns based on the tradition of the local village community or by Lodh (1991) referred to as the development of contextual financial accounting is an effort to maintain the existence of local socio-cultural aspects. Therefore, this research is driven by a desire to bring harmony between the village government financial management system and the traditions of rural communities built on awareness to give birth to a spirit of change in the socio-cultural and economic aspects of rural communities.

\section{Literature Review}

Rural from a sociological aspect has a social closeness among the village community. This closeness is because rural communities have relatively similar levels of homogeneity in livelihoods. Another aspect that has a homogeneous nature of religious beliefs that are similar in rural communities. The similarity in this aspect makes the community in the rural environment have social relations that are relatively very close and not distant. Awareness of the similarity of beliefs found in rural communities has triggered some religious-based business groups to utilize the situation as business opportunities such as the development of Islamic economics for rural communities (Kusmanto, 2014). Developing businesses based on religious values in rural areas because of the social reality of rural communities that still maintain religious practices well. Other evidence that indicates the life of the village community is very close to religious elements can be seen in the expression of gratitude for God's gifts that are arranged in the form of ceremonies or traditional activities.

Natural resources in rural areas and socio-cultural wealth including religious traditions that live in rural communities have formed a shared awareness to be able to manage this potential economically so that rural life can be better. Trisnawati, Wahyono, \& Wardoyo (2018) stated that the formation of a tourism village is an effort to empower rural communities by utilizing natural resources found in rural areas. The strategy of improving the rural economy through the establishment of a tourism village based on local potential is more empowering the potential 
contained in the community. The passage of a law on villages has directed the government to pay more attention to rural areas in the aspect of development. Of course, these efforts are not merely populist actions taken by the government, but other facts encourage the implementation of development programs based on rural areas. Road infrastructure as a link between regions is still inadequate (Suwarjoto, 2018), resulting in economic distribution being left untouched in rural areas, creating pockets of poverty (Priasto, 2015). The distribution channel of agricultural products, from land to market, has been delayed due to poor distribution of supporting infrastructure. This situation requires the government to take concrete steps to resolve the fundamental problems in the rural area.

However, the government's great attention on rural infrastructure development has not been balanced with development on social and cultural aspects including the religious dimension. The use of village funds is more dominated by the construction of rural public facilities such as village roads, office buildings, agricultural distribution channels while for local sociocultural aspects and the needs of religious support such as repairs and construction of houses of worship have not been well accommodated in the budget use policy. The Village Finance system application or better known as the Siskeudes is a software used to secure the policy of using the village budget. The instrument places village financial management based on formal nomenclature which is sometimes different from the reality of rural objectives.

In contrast to Brown (2017) who offer an agonistic conception which is further discussed in village financial negotiations namely accounting that is aspirational and open to being able to adjust to the environmental conditions and traditions of local village communities. Each village produces a financial management pattern called Dillard (2017) as a plurality of accounting/finance. Following the motto "Unity in Diversity" clearly written on a sheet that tightly grasps the symbolic state of Garuda Pancasila (Yudi, 2015), not just a motto that can be mentioned in every formal and informal conversation. Above all, this motto becomes an inseparable part of the diverse traditions in the lives of rural communities through the components of village financial management and accounting.

\section{Research Methods}

Science and Technology (Saintek) will continue to change along with the development of scientific methods and technological innovations. The discovery of science and technology is a consequence of the changing scientific method that continues to develop. The same situation occurs in the field of accounting, where knowledge develops through scientific discourse. The realm of accounting so far has been more developed through scientific research using a positivistic approach or better known as quantitative methods (Ghozali, 2004). While Djamhuri (2011) reminded that the existence of a qualitative paradigm in accounting research is needed not only to enrich the development of academics as a social science but also to prevent misconceptions in the eyes of the public that accounting is only a means of accountability information used in agency relationships.

This research uses a qualitative descriptive approach, which is a research method that seeks to present an objective picture of reality that occurs in a particular condition or environment in a particular place. Data collection methods using observation techniques, in-depth interviews by presenting open-ended questions to informants, study of literature and documentation. Descriptive qualitative research methodology is usually used to explore a condition in a formal or informal system to find a set of problems while offering solutions to problems that occur to break out of the shackles of the problem. The research location was in Sindang Pakuon Village, 
Cimanggung District, Sumedang Regency and Ciburial Village, Kec. Cimenyan, Kab. Bandung, West Java Province.

Stages of the study began from observation to the study site. Observations were made at the village government office, arts and cultural community groups, religious groups and several other groups that could confirm the information in this study. In-depth interviews by presenting open-ended questions to informants who have the competence to provide relevant information for this research. In addition to observational data and interviews, in conducting qualitative research requires documentation data (secondary) that can strengthen the observation data and in-depth interviews (Depth Interview). The collected data (Data Collection) is then tested using a triangulation validation technique. Validity and reliability in qualitative research are often called credibility tests. Creswell \& Miller (2000) offer several procedures to increase the credibility of data in qualitative research, namely triangulation, member checking, collaboration, and the audit trail. Triangulation techniques are used by researchers to test the validity of data by using various field data sources and comparing to verify the consistency of information. The member checking technique is carried out by following several stages, firstly every finding is discussed and its validity is checked with people in the organization who know the phenomenon of research. Both symptoms found on the research site are interpreted and discussed with other parties. The last technique of the validity of the data is the audit trail, Creswell \& Miller (2000) encourage researchers to consult the findings of research to external parties (independent) who have understanding and competence by research issues to assess the credibility of data collection. Moreover, findings and interpretations of researchers which have gone through the process of triangulation then becomes material to be analyzed and produces a model of village financial management systems that can encourage the preservation of local traditions of rural communities.

\section{Results}

The existence of village funds originating from central government allocations collected in the village government budget is important to be known by all elements of the community in the rural environment. Public awareness of village funds can increase community participation in carrying out their supervisory role. Kim \& Schachter (2013) argues that public participation can change governance for the better because the distance between the government as a servant becomes closer. The use of the village budget for the village development program can work better if it involves elements of the community in its implementation. The role of the community in supervision from planning to development responsibility to encourage village governments to improve the quality of management that is more transparent and accountable.

Community participation in village development is not limited to the role of passive supervision but rather plays an active role in providing solutions for village governments in overcoming village problems. Zeyn (2011) argues that public participation needs to be encouraged so that public services can become more quality, effective, and efficient and carried out in a transparent and accountable manner. Playing an active role in the community, the village government opens aspiration channels for the community when they want to submit proposals for development in rural areas. The proposed development can be in the form of physical or non-physical development. Physical development such as village infrastructure can stimulate the economic activities of rural communities. the development of social, cultural, and religious aspects in rural communities can encourage the birth of a harmonious life in the rural environment. Harmonization in the life of the village community becomes the basic capital in rural development in all aspects of social life. 
Conservation of rural local culture can be through the establishment of tourist villages based on the exploration of rural culture (Prakoso, 2015). These efforts are part of maintaining the existence of rural local culture by empowering rural communities. Another alternative is through optimization of village budgeting that opens space for development in all aspects of the rural environment including social, cultural and religious aspects. Both aspects have the same urgency. Socio-cultural and religious development in the village environment is formulated so that they do not overlap and can run synergistically, together with development on physical aspects such as infrastructure. The harmonization can encourage better socioeconomic changes for the life of the people in rural areas. Realizing this situation requires a village financial management system that is more accommodating to the local needs of rural communities.

The village financial management system that starts from planning, budgeting, implementing, administering and ending with accountability stands on the local paradigm of the local community. Considering the synergy between physical development and the traditions and local values of rural communities is a foothold in village financial management. Every element in the village financial management system, from planning to accountability contains local traditions and rural values. Local traditions and values can be in the form of cultural existence, social life and religiosity of rural communities that can inspire the management process. Accommodating the socio-cultural and religious needs of village communities in village finance can strengthen local values amidst the flow of development that enters into the rural areas. Pranadji \& Hastuti (2017) stated that the socio-cultural transformation was being experienced in rural areas. More deeply, Hatu (2011) explains the socio-cultural changes in rural communities is the implication of the introduction of communication and transportation technology in the village area.

Village financial management is formulated according to the values of the rural locality. What is the form of village financial management based on the value of rural locality? Every stage in village financial management from planning to accountability accommodates the sociocultural and religious needs of the community. Accommodating the needs of the socio-cultural aspects of society in village finance is an effort to preserve local traditions through financial instruments. Likewise in the aspect of religiosity, the needs of village communities for the support of religious facilities are accommodated in village finances. Values in the life of rural communities are often linked and interpreted by religious teachings (Setiawan, 2015), such a situation shows the importance of aspects of religiosity in the rural environment. Integration of socio-cultural aspects and the value of community religiosity into village finance can maintain the existence of local noble values and strengthen the values of village wisdom wherever possible.

\section{Financial Reality of Ciburial and Sindang Pakuon Villages}

As a village with an independent category, people in Ciburial villages on average have adequate economic life. Diversification in the profession of village communities is more varied indicating that Ciburial villagers have movements in economic activity. Some communities carry out activities in the government and private sectors. Out of these two sectors, the people of Ciburial Village work a lot in the fields of agriculture and vegetables. Geographically, the Ciburial village area has a hilly region landscape, being in the highlands can present a more attractive natural panorama and perspective so that it has the potential of a tourist destination (Mutiara, 2016). For people who want to enjoy the stretch of a row of buildings in the direction of Bandung City, Ciburial Village is one of the places. Its strategic location with the appeal of the natural environment attracts several entrepreneurs to invest in the Ciburial Village area, 
which began several years ago. Modern to classic cafe buildings stand close together and face to face can be found when entering the Ciburial village area through the west door access. In addition to the row of cafes, there is also a hotel business with star class until jasmine class, the investment results of entrepreneurs who come from outside the village of Ciburial. The scene looks different when entering the Ciburial Village area from the east. The community's hilly farms with cabbage-type plants and several short-term crops appear to fill vision along the way.

The natural potential contained in the Ciburial area is a potential income for the Ciburial village government. The entry of investment into the Ciburial village brings local original income for the village government which will later become a source of funding for development in the Ciburial village area. In addition to contributing income to the village government, the existence of business activities in the Ciburial village has opened up employment opportunities for the local community. Some villagers of productive age work in cafes and hotels in the village area. In addition, several other communities took advantage of the opportunity to establish cooperation, supplying foodstuffs originating from local agricultural products to the Cafe and Hotel. According to Dharmawan (2007), such conditions are sociologically a system of rural livelihoods and livelihoods in a home industry scheme. Therefore Investment in the ciburial village has had an impact on the economic life of the community and helped the ciburial village government realize its development.

In the last three years the development carried out by the Ciburial village government has been dominated by physical development, especially on road infrastructure and buildings. Development of public infrastructures such as village roads and government buildings still dominate in village planning. Although the benefits of village development have been felt, there are still other aspects that have not been touched by development even though it is an important part of the life of the village community namely, religious aspects. The regulations on the use of village budgets which are patented in the nomenclature node make religious aspects in the form of construction and rehabilitation of places of worship impossible. In an interview at the Ciburial Village Office with Mr Tiar Gustirawan, as Head of Planning said "... repairs or renovation of the mosque, we from the Village Planning Team cannot include in the planning of the development field because the budget slot (Nomenclature) is not available in the Village Financial System (Siskeudes) ". Still, in the atmosphere of an interview with $\mathrm{Mr}$ Tiar, one opportunity stated that "Although the community's proposal for repair or renovation of the mosque had been rejected, the proposal still appeared the following year in the village meeting (Musdes), even though it had been socialized to all $R W$ management not to propose repair or renovation of the mosque ". The statement was confirmed by Mr Ayi Sumarna, as Head of Financial Affairs in an interview on a different day, at the Ciburial Village Office. "... indeed in several times the Village Deliberation organized by the Village Representative Body $(B P D)$ there are still members of the Rukun Warga $(R W)$ in Ciburial village suggesting mosque repairs and renovations but they are still rejected because there are no budget slots".

The statement from the informant above is validated by presenting other informants who have a higher position in the village financial management structure. This technique is known as the informant data triangulation method. Mr Asep Rahmat is an official of the Village Secretary in the Ciburial village government structure. His position as secretary of the village, as well as placing him as the Village Finance Management Authority (PKPKDes) following the provisions set out in the Minister of Home Affairs Regulation No. 20 of 2018 concerning Village Financial Management. One of the tasks carried out by the Village Financial Management Authority (PKPKDes) is to act as the coordinator in the Village Planning Team. In an interview in the workroom, Mr Asep Rahmat said "... I as the coordinator of the village 
planning team sometimes still meet the proposed development program from the residents of the Rukun Warga $(R W)$ in Ciburial village, but it has not been realized by the village government because it is related to budget rules. "For example repairing a mosque". In addition to conducting interviews with elements of village officials, other data sources were obtained from interviews with religious community groups represented by the Kyai. $\mathrm{H}$. Muchtar Adam. A founder and caregiver of the Babussalam Islamic Boarding School since 1980 in the Ciburial village area. During an interview at Mr Kyai's house. H. Muchtar Adam who is still in the Islamic boarding school Babussalam said, "... the people in the Ciburial village, the people are religious, obedient to the teachings of religion and I have witnessed myself since settling in this Ciburial from the 1980s".

Unlike the conditions in the Ciburial village, the Sindang Pakuon village region demographically has a population with varied ethnic backgrounds. Residents from Central Java Province and Yogyakarta Special Region became the dominant migrants who occupied the Sindang Pakuon village area. Some newcomers come from the island of Sumatra, but there are not as many as the previous two provinces. Indigenous people themselves are increasingly diminishing because most of their citizens have moved to other areas outside the village of Sindang Pakuon. Selling land assets is the most reason why the original inhabitants of Sindang Pakuon Village moved to leave their homeland. Although some have sold land assets, there are still some among the indigenous people living in the village area because they have more than one point of land in the village area of Sindang Pakuon. For indigenous people who do not own land, some of whom still survive in the Sindang Pakuon area by occupying rented houses. At present, the indigenous people occupy the "upper" area which is the edge of the Sindang Pakuon village area for settlement.

Since Law No. 04 of 2016 has been effective, the Sindang Pakuon village government has experienced a leadership transition twice. In the first leadership held by Mr Yusuf and in the second leadership held by Mr Yudi Hamdansyah who was elected through the electoral contestation at the village level Sindang Pakuon. Although the head of government has changed twice, the ranks of the village bureaucracy in Sindang Pakuon have not changed. The leadership transition in the village of Sindang Pakuon for the ranks of village officials is felt differently. The leadership style adopted by the new village head is different when compared to the previous village head. Such conditions for the ranks of village officials need to harmonize in bureaucratic interaction. Some things can work synergistically between village officials and the village head, but some other things cannot because they conflict with the provisions stipulated in the regulations.

Uniforming national nomenclature in village financial management patterns causes obstacles in financial administration to be felt by village governments similar to one another. Financial administration obstacles experienced by the Ciburial Village Government were also felt by the Sindang Pakuon Village government. Certain aspects have not been accommodated in the village financial nomenclature. The religious aspect which is one of the main elements in the life of the village community escapes the reach of the nomenclature. This situation creates obstacles for the government and the village community when developing religious aspects. Of course, this situation is ironic, rural communities in the archipelago known sociologically have a higher level of vertical transcendence when compared to urban communities, but instead, have no space in accessing village finance in religious matters. Sulina et al (2017) believe that inputting data in the village financial system must be in accordance with what is stated in the system or in other words the village financial application operator cannot input if it is not following the village financial nomenclature. This nomenclature standard then becomes an 
obstacle in the physical development of religious aspects such as the construction and rehabilitation of houses of worship. Such is the case faced by the Sindang Pakuon villagers when proposing the construction or rehabilitation of places of worship, each year experiencing rejection from the village government on the pretext of nomenclature not accommodating these activities. In an interview with the Sindang Pakuon Village Secretary "... indeed, we from the Sindang Pakuon Village Government have not been able to realize the community's proposal for the construction, renovation, or repair of the mosque because the budget post is not in the Village Financial Information System, But." Said the village secretary, still in the atmosphere of the interview "The village government has budgeted for activities that have a religious nuance like yesterday, in the month of Ramadan, we filled with several competition activities, one of which was the Adhan Competition for children".

\section{Waning Mutual Cooperation Tradition}

Viewed from a sociological perspective, rural communities have stronger social ties when compared to urban communities. Homogeneous professional background causes the social and economic ties of rural communities to be very close (Jamaludin 2015). Professional homogeneity in rural communities is more common in the agricultural sector. Rural communities depend more on life in this sector. For the village of Ciburial itself, most of the people have a source of income from agricultural activities. Having the same professional background in the agricultural sector makes the farmers when facing agricultural problems, one and the other will build communication to find solutions together. The communication that has been developed continues to be a social bond between rural communities which further strengthens social relations in the rural environment. A concrete manifestation of the solidity of social ties among villagers can be seen in the mutual cooperation tradition that colours the lives of rural communities.

The solidity of rural communities can still be observed in the mutual cooperation tradition. Anggorowati \& Sarmini (2015) argued that the government's efforts to maintain in maintaining the tradition of mutual cooperation by force and voluntary. In contrast to previous efforts, the government through the village government is now introducing the concept of mutual cooperation with rewards or called the Cash Solid Work Program. Herdiyana (2019) argues that cash-intensive labour can increase the purchasing power of the poor in rural areas because it is intensive. Empowering underprivileged people in infrastructure development activities by providing wage compensation for work is the government's effort to increase the purchasing power of the poor in the village. It is expected that by providing wages to the poor, purchasing power will increase so that it can meet the daily operational needs of households.

In the course of several budget years, cash-intensive programs have had a positive impact on the poor in rural areas. Villagers who receive wages through the Cash Intensive Work program can more easily meet the needs of family life. The cash-for-cash program has succeeded in making an economic contribution to disadvantaged villagers (Manembu, Kusen, \& Deeng, 2019). At a macro level, cash-intensive programs also provide positive indications for the economy of rural areas which are marked by a decrease in unemployment. The implementation of cash-intensive programs has brought economic benefits to rural areas on the one hand, but on the other hand, the program also has implications for the decline in the value of rural local traditions such as the decline in mutual cooperation. The emergence of what is called the decadence of the spirit of mutual cooperation in rural communities.

Village infrastructure development activities are carried out by the village government together with the village community. This joint work process is what distinguishes it from the 
central/regional government when procurement of infrastructure is carried out through tenders. Village infrastructure works, one of which is village roads, is carried out cooperatively by the village community without receiving work wages. The community builds public facilities voluntarily with the awareness that this facility will be used by the village community itself. Nevertheless, there are still groups of people still reluctant to be involved in mutual cooperation activities (Hardianti, 2015). Even so, research on community participation in village road infrastructure development is divided into three forms of participation, namely the contribution of labour, materials, and plants (Kogoya, Olfie, \& Laoh, 2015). The central government policy implemented by the village government to provide workers' wages in infrastructure works has made the spirit of mutual cooperation decline. The spirit of mutual cooperation of the village community to participate in the implementation of village development began to fade due to intensive stimulation. The Cash Intensive Work Program (PKT) for example for the construction of concrete rebates, some workers involved in construction receive wages while others do not. The difference in compensation caused a decrease in tolerance among villagers and resulted in the fading of the spirit of mutual cooperation among the village community. In an interview with Mr. Tiar Gustirawan, as Head of Planning said in an interview at the Ciburial Village Office. "... we acknowledge that cash-intensive labour (PKT) is very helpful for poor people, recipient residents are selected strictly by us (village government). ... the impression arose in the community that the village road works that had been done in mutual cooperation, there was a pay.

A similar situation occurred in the village of Sindang Pakuon, District of Cimanggung, Sumedang Regency, West Java Province, a village with more inhabitants inhabited by migrants. Although the demographic and socio-economic conditions of the people of Ciburial and Sindang Pakuon villages differ, they have similarities in the implementation of village financial management rules. Village financial management refers to regulations originating from the central government, then replicated into local regulations and becomes a reference for village governments in implementing financial governance. Sourced from the same regulation will produce similarities in the implementation of village government financial management wherever located. Community empowerment stimulated through village government budgets can reduce unemployment in rural areas (Azizah, Zauhar, \& Soeaidy 2015), Cash Intensive Work (PKT) is part of a program to reduce unemployment. Community participation in the village of Sindang Pakuon in mutual assistance in infrastructure development began to diminish because the cash-for-work program (PKT) required paying compensation to some of the communities involved, while others did not receive it. The different treatment creates an imbalance among people who participate in development activities in mutual cooperation. This situation gives rise to demoralizing attitudes towards groups of people who do not enjoy wage compensation.

\section{Integration of Local Dimensions into Village Finance}

The village financial nomenclature contained in the Village Financial System (Siskeudes) application has been applied to all village governments in Indonesia. The Village Finance System application can make it easier for village officials to administer village finances. Wilma \& Hapsari (2019) believes that the application of the village financial system also functions as a means of monitoring village financial management. Although the application of the village financial system (Sistem Keuangan Desa /Siskeudes) can provide financial administration facilities, on the other hand, the application raises a reductionist value of the uniqueness of each village due to the standardization of nomenclature inherent in Siskeudes. The uniqueness can be in the form of socio-cultural characteristics found in the village community. Another uniqueness of the rural community is the strong vertical transcendence relationship in colouring 
everyday life in the countryside. These two aspects are the characteristics of the village which can be capital in building harmonious life in the rural environment to lead to the harmonization of national life with the motto Unity in Diversity. Reforming village financial management by opening up space for local elements to be included in village financial nomenclature is an important step so that the preservation of local values is maintained. Kasaliku Junti said Sundanese language which means "domination of foreign culture can replace local culture," Abah Olot said in an interview, a Sundanese artist who tenaciously defended and preserved traditional Sundanese Karinding instruments amid the dominance of modern musical instruments.

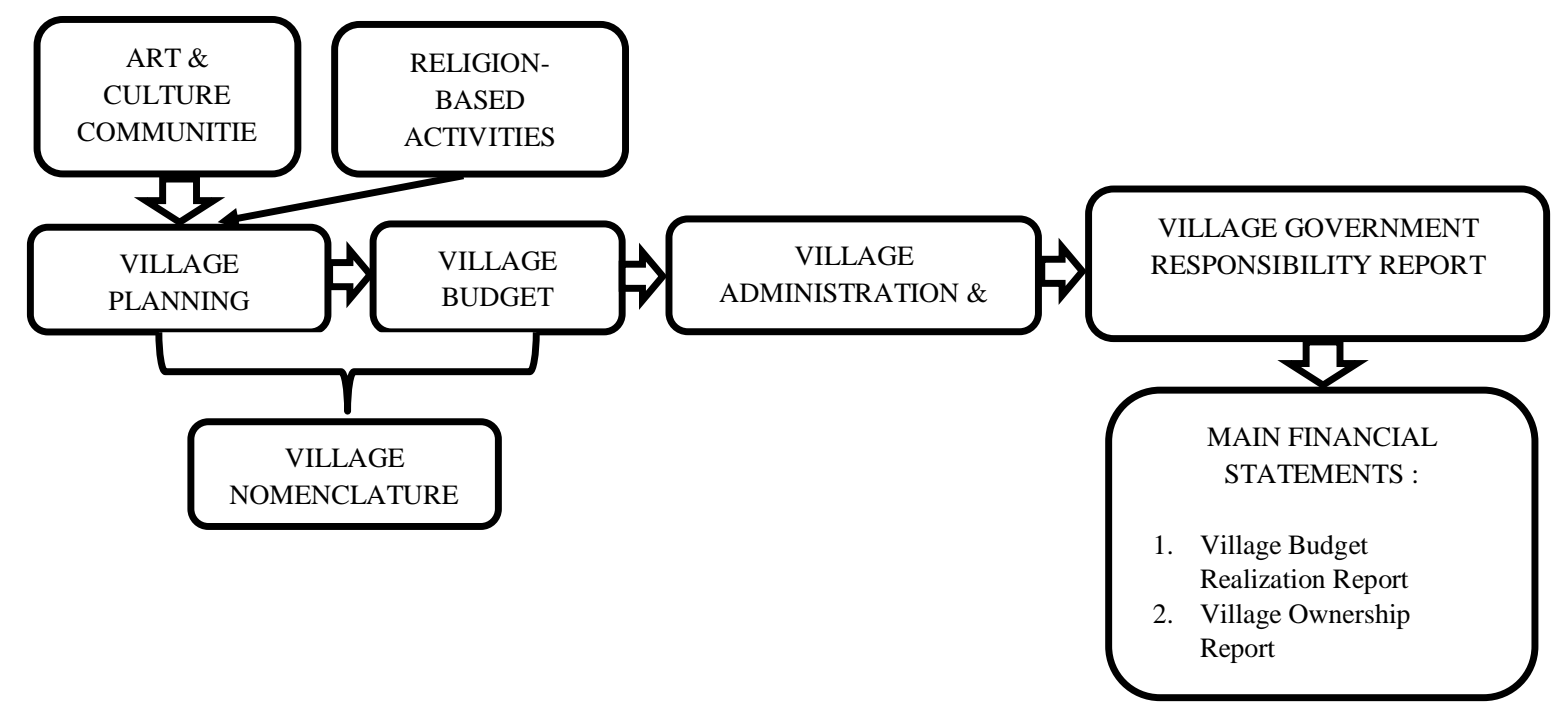

Figure 1. Village-Based Local Financial Management

Providing space for local elements in the pattern of village financial management is an effort to preserve local traditions which from the beginning have been a part of the social life of rural communities. Pranaji \& Hastuti (2004) in their research explained that rural socio-cultural transformation is an urgent need, especially to catch up with rural communities. Providing space for the element of turbulence in the budget nomenclature can maintain the existence of local traditions that are owned by each rural environment, where each other has differences. The diversity of socio-cultural aspects in each rural community is a natural reason for certain in each rural area. any socio-cultural uniqueness found in the rural environment will be a reference in the formulation of the local village nomenclature. The details of the number of local nomenclatures will be in accordance with the many traditions that live during the village community. Each village has a different type of local nomenclature due to other villages because each village has a diversity of traditions. Likewise, with the religious aspect, the village financial nomenclature opens space for aspects of religiosity that have long been rooted in rural community life.

The community is the target of the administration of public services organized by the village government. Involving the community in the formulation of public services is a way for the village government to make public services more targeted. An important development program invites community participation in all stages of development in rural areas (Dewi, 2013). Sociocultural and religious aspects included in village financial nomenclature can encourage community participation in development planning and participate in the development. Village communities can channel their aspirations that are related to socio-cultural and religious aspects through the Village Deliberation Forum. Community aspirations about religious 
aspects are often rejected by the Village Development Planning Team on the pretext that "nomenclature" does not happen again. Rationalizing local nomenclature for the value of "uniqueness" can be an opportunity for creativity for the village government together with the community to optimally manage all the potential possessed by the village.

\section{Conclusion}

This study focuses on exploring the socio-cultural reality of rural communities, laden with contextual nuances so that it becomes a critical study of village financial management regulations. Giving birth to an "alternative model" of village financial management from a contextual critical study is one step in raising social, cultural and religious aspects that have not yet been accommodated in village finance. This study uses a qualitative method approach that explores the realities found in the Government of Ciburial Village and Sindang Pakuon. The qualitative method approach in this research is contextual in nature and the results only apply to the location (site) where the research was carried out. External validity is limited to this study making the nature of generalization can not be applied to other villages outside the village of Ciburial and Sindang Pakuon. Although there are limitations on External validity, it has strengths in internal validity so that this research can be a foundation for future researchers when using a positivistic (quantitative) approach which contains wider aspects of External validity that has the potential to generalize.

The face of the village has experienced significant changes in the last few years. The development of basic infrastructure in rural areas has brought about change and has benefited the community in supporting the village's social and economic activities. Unlike when the village has not been regulated separately in the law as it is today, village infrastructure is still limited causing community mobilization and distribution of local production of the community to be hampered. Even though the condition of the rural area is currently getting better, there are still aspects of rural community life that have not been touched by village finances, namely the aspect of worship facilities. This aspect has not been accommodated in the budget nomenclature so that the worship and development activities can not be implemented by the village government. In addition, the degradation of the village community mutual cooperation spirit is another implication of the Cash Intensive Work (PKT) policy currently being implemented by the village government. The integration of the local dimensions of village communities into village financial nomenclature is an important step to reduce the social biases arising from the village budget which is currently used to carry out village government functions.

\section{Acknowledgement}

This research was carried out using funding sources from the Directorate of Research and Community Service, the Directorate General of Research and Development Strengthening, the Ministry of Research, Technology and Higher Education.

\section{References}

1) Anggorowati, P., \& Sarmini, S. (2015). Pelaksanaan Gotong-Royong di Era Global (Studi Kasus di Desa Balun Kecamatan Turi Kabupaten Lamongan). Kajian Moral dan Kewarganegaraan, 1(3), 39-53.

2) Azizah, R. N., Zauhar, S., \& Soeaidy, M. S. (2015). Pemberdayaan Masyarakat Dalam Mengurangi Angka Pengangguran di Kabupaten Sampang. WACANA, Jurnal Sosial dan Humaniora, 18(3). 
3) Bay, C. (2018). Makeover accounting: Investigating the meaning-making practices of financial accounts. Accounting, Organizations and Society, 64, 44-54.

4) Brown, J. (2017). Democratizing accounting: Reflections on the politics of "old" and "new" pluralisms. Critical Perspectives on Accounting, 43, 20-46.

5) Creswell, J. W., \& Miller, D. L. (2000). Determining validity in qualitative inquiry. Theory into Practice, 39(3), 124-130.

6) Dewi, M. H. U. (2013). Pengembangan desa wisata berbasis partisipasi masyarakat lokal di Desa Wisata Jatiluwih Tabanan, Bali. Jurnal Kawistara, 3(2).

7) Dharmawan, A. H. (2007). Sistem penghidupan dan nafkah pedesaan: pandangan sosiologi nafkah (livelihood sociology) mazhab barat dan mazhab Bogor. Sodality: Jurnal Sosiologi Pedesaan, 1(2).

8) Djamhuri, A. (2011). Ilmu Pengetahuan Sosial dan Berbagai Paradigma dalam Kajian Akuntansi. Jurnal Akuntansi Multiparadigma, 2(1), 147-185.

9) Ghozali, I. (2004). Pergeseran Paradigma Akuntansi dari Positivisme ke Perspektif Sosiologis dan Implikasinya terhadap Pendidikan Akuntansi di Indonesia.

10) Hardianti, S. (2015). Partisipasi masyarakat dalam pembangunan infrastruktur desa (program alokasi dana desa di Desa Buntongi Kecamatan Ampana Kota). Katalogis, 5(1).

11) Hatu, R. (2011). Perubahan Sosial Kultural Masyarakat Pedesaan (Suatu Tinjauan TeoritikEmpirik). Jurnal Inovasi, 8(04).

12) Herdiyana, D. (2019). Implementasi Padat Karya Tunai dalam Menurunkan Penduduk Miskin di Pedesaan Provinsi Lampung dan Riau. Equilibrium: Jurnal Penelitian Pendidikan dan Ekonomi, 16(02), 175-187.

13) Jamaludin, A. N. (2015). Sosiologi Perdesaan.

14) Kim, S., \& Schachter, H. L. (2013). Citizen participation in the budget process and local government accountability: Case studies of organizational learning from the United States and South Korea. Public Performance \& Management Review, 36(3), 456-471.

15) Kogoya, T., Olfie, B., \& Laoh, O. E. (2015). Partisipasi Masyarakat Terhadap Pembangunan Infrastruktur Jalan Desa di Kabupaten Lanny Jaya-Papua. Jurnal Berkala Ilmiah Efisiensi, 15(02).

16) Kusmanto, T. Y. (2014). Pengembangan ekonomi Islam berbasis kependudukan di perdesaan. Jurnal Ilmu Dakwah, 34(2), 219-235.

17) Lodh, S. (1991). A critical theory approach to management accounting research.

18) Manembu, R. R., Kusen, A. W., \& Deeng, D. (2019). Padat Karya Sebagai Kontribusi Kehidupan Masyarakat pada Penggunaan Dana Desa (Studi Kasus Desa Kaneyan Kecamatan Tareran Kabupaten Minahasa Selatan). Holistik, Journal of Social and Culture.

19) Prakoso, A. A. (2015). Pengembangan Wisata Pedesaan Berbasis Budaya Yang Berkelanjutan Di Desa Wisata Srowolan Sleman. Jurnal Kepariwisataan, 9(2), 61-76.

20) Pranadji, T., \& Hastuti, E. L. (2017). Transformasi sosio-budaya dalam pembangunan pedesaan. Analisis Kebijakan Pertanian, 2(1), 77-92.

21) Priasto, A. (2015). Summary of Indonesia's Poverty Analysis. Asian Development Bank Papers.

22) Setiawan, W. (2015). Geneologi Penafsiran Agama Masyarakat Pedesaan. Akademika: Jurnal Pemikiran Islam, 20(1), 47-68.

23) Sulina, I. G. A. T., Wahyuni, M. A., Kurniawan, P. S., \& ST, M. (2018). Peranan Sistem Keuangan Desa (Siskeudes) terhadap Kinerja Pemerintah Desa (Studi Kasus di Desa Kaba-kaba, Kecamatan Kediri, Kabupaten Tabanan). JIMAT (Jurnal Ilmiah Mahasiswa Akuntansi) Undiksha, 8(2).

24) Suwarjoto, I., A. (2018). Infrastructure Expenditure And Poverty Reduction In Indonesia. Russian Journal of Agricultural And Socio-Economic Sciences 4(76).

25) Toms, S., \& Shepherd, A. (2017). Accounting and social conflict: Profit and regulated working time in the British Industrial Revolution. Critical Perspectives on Accounting, 49, 57-75.

26) Trisnawati, A. E., Wahyono, H., \& Wardoyo, C. (2018). Pengembangan Desa Wisata dan Pemberdayaan Masyarakat Berbasis Potensi Lokal. Jurnal Pendidikan: Teori, Penelitian, dan Pengembangan, 3(1), 29-33. 
IJBE (Integrated Journal of Business and Economics)

e-ISSN: 2549-3280/p-ISSN: 2549-5933

27) Wilma, A. A., \& Hapsari, A. N. S. (2019). Analisis Implementasi Pengelolaan Dana Desa Menggunakan Aplikasi Siskeudes Desa Banyuanyar. Perspektif Akuntansi, 2(2), 169-193.

28) Yudi, L. (2015). Negara Paripurna. Gramedia Pustaka Utama, Jakarta.

29) Zeyn, E. (2011). Pengaruh good governance dan standar akuntansi pemerintahan terhadap akuntabilitas keuangan dengan komitmen organisasi sebagai pemoderasi. Jurnal Reviu Akuntansi dan Keuangan, 1(1), 21-36. 